\title{
17 \\ The Rumble of Think Tanks: National Security and Public Policy Contestability in Australia
}

\author{
Allan Gyngell
}

\section{Introduction}

Australia was late in developing a foreign policy separate from British imperial policy. Legislation to implement the Statute of Westminster establishing Australia's full sovereign identity was not passed until 1942. Partly because of this, engaged individuals and institutions outside government have always played a role in shaping ideas about, and public attitudes towards, the way Australia protects and advances its international interests.

This chapter looks at one comparatively recent dimension of that nongovernment involvement in Australian public policy, the role of think tanks in Australian defence and foreign policy. It examines the reason for their emergence around the turn of the twenty-first century against the background of earlier efforts to shape public policy, assesses the contribution they have made, and explores their future.

From the 1970s onwards, Robert O'Neill played an important part in the development of some of most important of these institutions. From 1971-1982 he was head of the Strategic and Defence Studies Centre (SDSC) at The Australian National University. Then, after his return 
from London and Oxford, he was involved in the formation of the Australian Strategic Policy Institute (ASPI) in Canberra, the Lowy Institute for International Policy in Sydney, and the United States Studies Centre at the University of Sydney.

In his 2006 Lowy Lecture, 'Problems and Perspectives on International Security', O'Neill described the qualities Australian think tanks needed to bring to the task of assisting policy-makers deal with contemporary security challenges:

[W]e need good ideas, dialogue with government and a relationship which tolerates free expression of views, especially on differences with existing policies. None of these essentials comes easily. We, the analysts, need experience in practical work - diplomacy, war, business and politics - as well as intellectual quality before we have any notion as to what is a good idea. Once we develop some ideas we need to be able to discuss them with senior people in government so that our views are taken into account in the mix that goes into decision-making. Our colleagues in government will not bother to listen to us if they do not respect the relevance and quality of our work. It is up to us to win their attention and hold it. ${ }^{1}$

\section{What is a Think Tank?}

The concept of a think tank is, as Thomas Medvetz writes, 'fuzzy, mutable and contentious'. ${ }^{2}$ A broadly accepted definition used in the development of the most prominent think tank rating system is that they are

public-policy research, analysis and engagement organizations that generate policy-oriented research, analysis, and advice on domestic and international issues, thereby enabling policymakers and the public to make informed decisions about public policy. Think tanks may be affiliated or independent institutions that are structured as permanent bodies, not ad hoc commissions. These institutions often act as a bridge between the academic and policymaking communities and between states and civil society, serving in the public interest. ${ }^{3}$

1 O'Neill, Robert (2006) 'Problems and Perspectives on International Security', The Lowy Lecture on Australia in the World, 27 November, Sydney: Lowy Institute for International Policy.

2 Medvetz, Thomas (2012) Think Tanks in America, Chicago: University of Chicago Press.

3 McGann, James G. (2013) 2013 Global Go To Think Tank Index Report, Philadelphia: University of Pennsylvania. 
Think tanks differ from the much larger group of non-government organisations (NGOs), advocacy groups, industry associations, online communities, and university research centres which are also trying to influence public debate and the direction of public policy, in that think tanks:

- exist for the primary purpose of undertaking applied research in public policy and shaping policy outcomes;

- are not-for-profit institutions;

- have a breadth of focus which can be broader or more limited, but which extends beyond a single narrow cause - oceans, for example, but not highly migratory tuna; and

- contribute to the public debate; that is, they conduct their principal work in the public realm.

Some think tanks look across many dimensions of public policy (e.g. Brookings). Others, look more narrowly at a particular area (e.g. Peterson Institute for International Economics, the Center for Strategic and International Studies).

Some emphasise the independence of view of individual researchers and their broad and non-partisan approach (e.g. Brookings, the International Institute for Strategic Studies). Others, such as Heritage, Cato, or the Center for American Progress in Washington bring to the job a particular philosophical approach. In Australia, the Centre for Independent Studies describes itself as 'engaged in support of a free enterprise economy and a free society under limited government', while the Australia Institute pursues what it terms a progressive agenda.

The term 'think tank' is now used to describe institutions ranging in size from the RAND Corporation, with its 1800 staff and revenue of US $\$ 269$ million, to a couple of part-time bloggers with some strong views. An estimated 6,828 think tanks operate internationally, with nearly 400 of them in Washington DC. ${ }^{5}$ Australian numbers are much 
smaller and depend on definitions. One recent estimate puts the number of 'main think tanks' in Australia at 12, but acknowledges that definitions are fluid and the number is always in flux. ${ }^{6}$

Some scholars adopt a more theoretical approach to think tanks. Medvetz defines them as occupying 'a distinct subspace of knowledge production which has arisen over time at the point of intersection between the academic, political, economic and media fields'. ${ }^{7}$ They have emerged, he argues, through the very process of practically differentiating themselves from their surrounding fields of universities, lobby groups, and media outlets, increasingly orientating themselves towards each other, until they have come to constitute 'a semi distinct social universe with its own logic, history, and interior structures, not to mention its own agents' ${ }^{8}$

It is certainly true that strict typologies of think tanks fail to account for the regular changes and adaptations to new pressures and demands which we see even in the much smaller field of Australian think tanks. Nor do they adequately represent the fluid spectrum between university-based centres such as SDSC which undertake some public policy research and outreach and the work of stand-alone institutions undertaking applied research in public policy. (One clear difference in Australia is that Australian Research Council funding is available only to researchers within the university system.)

Even the origin of think tanks is disputed. Some scholars point to the Duke of Wellington's establishment of the forerunner of the Royal United Services in 1831; others to the formation of the Royal Institute of International Affairs (Chatham House) in $1920 .{ }^{9}$ But in the broad sense in which think tanks are currently defined, a critical step came in 1916 when Robert S. Brookings and others formed the Institute for Government Research in Washington DC, the first private institute devoted to the 'fact-based study of national public policy issues'. ${ }^{10}$ Eleven years later, this became the Brookings Institution.

6 Milliken, Robert (2105) 'An Incisive Guide to Australia's Think Tanks', Anne Summers Reports 11, pp. 35-45.

7 Medvetz, Thomas (2012) Think Tanks in America, Chicago: University of Chicago Press.

8 Ibid.

9 For an excellent contemporary survey of this history, see Roberts, Priscilla (2015) 'A Century of International Affairs Think Tanks in Historical Perspective', International Journal 70(4).

10 www.brookings.edu/about/history. 
After the Second World War, as governments faced new strategic and economic challenges which demanded fresh technocratic solutions, the growth of think tanks blossomed and their forms multiplied. The term came into wider use with its current meaning during the 1970 s. ${ }^{11}$

However they are defined, think tanks help structure the public debate, shaping public understanding of the world by providing an alternative source of views about it. The views from think tanks are typically different from those generated in other areas of the public debate: less cautious than from the public service; less shortterm than most media commentary; but more immediate than most academic work.

Because the coinage of think tanks is the production of new ideas, think tanks need to be alert to developments in the world. Successful think tank staff demonstrate a combination of attributes which are often very different from those required in the fields from which many of them come, such as the public service or academia. In addition to subject knowledge, they need to know how governments and businesses operate in the real world, to understand and utilise the link between knowledge and power, and to be skilful advocates.

Think tanks can float ideas that are too risky for governments. They can more easily bring together groups with different interests to work through problems and they can facilitate second track diplomacy - more informal and indirect channels of communication between countries.

\section{The Role of Non-government Institutions in the Development of Australian International Policy}

Efforts by members of the public to define and deepen the debate in Australia about international policy began early in the life of the new Commonwealth. Groups such as the Round Table and Chatham House, 
and later the Australian Institute of International Affairs (AIIA), began the process of arguing for the development of an Australian role in the formulation of imperial policy.

If the establishment of Chatham House marks one step in the appearance of the modern think tank, it is important to note that Australians were present at the inaugural meetings in May 1919 in Paris - John Latham was charged with preparing the summary of the proceedings. John Latham, Frederic Eggleston and Robert Garran returned from Paris as members of the emerging institution; local branches of Chatham House were established in 1924-1925 and the Australian Institute of International Affairs was reorganised as a national body in 1933. Meanwhile, a local manifestation of the Institute of Pacific Relations - the first genuinely regional (in this case, trans-Pacific) think tank - was established in 1925, eventually working as part of the AIIA. From the first, the individuals concerned (scholars, practitioners, and commentators were all participants) were devoted to promoting public enlightenment on issues of foreign affairs, to sponsoring and authoring studies of contemporary international issues of particular relevance to Australia (the first in 1928), and in particular to exploring options for policy. Membership of the Chatham House, the Institute of Pacific Relations, and the International Institute of Intellectual Cooperation (established in 1926) networks brought Australian commentators and scholars into contact with advanced analysis in the new discipline of international relations, while also opening the way to the first funding of work in Australia by international foundations, notably Rockefeller and Carnegie. The first time the phrase 'Australian Foreign Policy' was used as a book title was in an AIIA symposium volume, Australian Foreign Policy 1934; ${ }^{12}$ the most comprehensive study of Australia's perceptions of regional security to that date was in the AIIA work Security Problems in the Pacific Region. ${ }^{13}$ Until the 1960s, the AIIA, especially through its journal Australian Outlook (founded in 1947), was unrivalled as a focus for analysis and debate in the fields of foreign and security policy. ${ }^{14}$

12 Dinner, Hector and J. G. Holmes (eds) (1935) Australian Foreign Policy 1934, Queensland: Australian Institute for International Affairs.

13 Buesst, Tristan, W. Macmahon Ball and Gerald Packer (1949) Security Problems in the Pacific Region, Melbourne: Robertson \& Mullens.

14 I am indebted to James Cotton for his contribution to this section. 
The establishment of The Australian National University in 1946 was linked to ideas of national development and to the requirements of public policy. In 1966, the Strategic and Defence Studies Centre was established under Dr T. B. Millar, separate from the work of the International Relations Department, to advance the study of Australian, regional and global strategic and defence issues as the country came to terms with dramatic changes in Asia and the beginning of the Vietnam War. The centre was also seen as a way of attracting external funding to the university, first from the Ford Foundation and later from the Australian Defence Department. ${ }^{15} \mathrm{O}^{\prime}$ Neill became the centre's second director in 1971 and stayed until 1982, strengthening its position within the university, securing its finances, and cementing its role as a proto-think tank, engaging directly with the policy-advising and policy-making community.

Outside the university system, the AIIA continued its essentially educational role, its constitution preventing it from expressing particular opinions on any aspect of international affairs, although its precise objectives continued to be the subject of debate within the organisation. ${ }^{16}$ A private, not-for-profit Pacific Security Research Institute focused on foreign and defence policy was established in Sydney in April 1989, with Owen Harries as president, and former diplomat, David Anderson, as executive director. It was short-lived, but published several papers and held two conferences. ${ }^{17}$

At the same time, groups such the Institute for Public Affairs in Melbourne and the Sydney-based Centre for Independent Studies were pursuing free-market, liberal, and libertarian philosophies largely in the areas of economic and social policy.

15 Thatcher, Meredith and Desmond Ball (2006) A National Asset: Essays Commemorating the 40th Anniversary of the Strategic and Defence Studies Centre, Canberra: Strategic and Defence Studies Centre, The Australian National University.

16 Legge, John D. (1999) Australian Outlook: A History of the Australian Institute of International Affairs, Sydney: Allen \& Unwin.

17 Thatcher, Meredith and Desmond Ball (2006) A National Asset: Essays Commemorating the 40th Anniversary of the Strategic and Defence Studies Centre, Canberra: Strategic and Defence Studies Centre, The Australian National University. 


\section{The Turn of the Century Expansion of Think Tanks}

It was not until the beginning of the twenty-first century, however, that think tanks became a more established feature of policy development in Australia. This section examines the reasons for this sudden expansion. Elements of chance were involved (the 50th anniversary of the arrival in Australia of a prominent businessman), but more important were the changes taking place in each of the three domains within which think tanks operated - government, research, and media.

\section{Government}

From the mid-1990s onwards, but most notably between the Asian financial crisis of 1997-1998 and the Al Qaeda attacks on the World Trade Centre in 2001, the implications of the revolution in information technology - digital communications, personal computing, and mobile telephony - which underpinned economic globalisation became fully apparent to policy-makers.

As the cost of transferring information around the world was reduced to near zero, the relative power in the international system of state and non-state actors shifted. Groups ranging from transnational corporations, through internationally networked NGOs, to terrorists and transnational criminals, were empowered and found new and more effective ways of acting together.

One consequence for Australian governments, as for others, was to erode the barriers between domestic and international policy. By 1997, the Howard Government's foreign and trade policy White Paper, In the National Interest, was calling for a 'whole-of-nation approach which emphasises the linkages between domestic policies and foreign and trade policies' ${ }^{18}$ New transnational issues on the international agenda, such as climate change, involved many different departments and agencies.

18 Department of Foreign Affairs and Trade (1997) In the National Interest, Canberra: Australian Government Public Service. 
In particular, ideas about national security - what it was, who was responsible for it, and how it was delivered — changed fundamentally after 9/11. Governments faced a range of difficult new questions. Were the intelligence agencies, the defence forces, and the police adequate to deal with the new challenges of terrorism and asymmetric warfare? How should they work together? How could non-state actors be deterred? More aspects of public policy, from transport to social policy, were becoming securitised. Just as the earlier generation of think tanks, notably the International Institute for Strategic Studies (IISS), which O'Neill had led, had been a response to the complex strategic challenges thrown up by the arrival of the nuclear age, so new thinking was now required about these difficult questions.

In a parallel process, the expansion of neoliberal thinking through the 1980s and 1990s had led to a normative change in public administration in favour of contestable policy advice and competitive project delivery. ${ }^{19}$ Think tanks and commercial consultancies were beneficiaries as governments began deliberately to seek advice outside the regular channels of the public service.

\section{Research}

Universities were also changing, driven by a more demanding and competitive market for students, and the need to prove their relevance to governments. One response was the establishment of new centres, such as SDSC, which combined teaching, research and public outreach. The Centre for International Security Studies at Sydney University (established in 2006) and the National Security Institute at the University of Canberra (founded in 2007) were examples. At the same time, however, the academic reward system - based on student numbers and driven by publication in peer-reviewed academic journals - was fundamentally different from that required to succeed as a think tank, where the key measurements of success were entrepreneurial skills, and access to and influence upon policymakers. Universities struggled as think tanks.

19 Keating, M. (2000) 'The Pressures for Change', in G. Davis and M. Keating (eds), The Future of Governance: Policy Choices, Sydney: Allen \& Unwin. 


\section{Media}

It was becoming clear from the early years of the century that the business model for newspapers in Australia, especially broadsheet newspapers, which depended heavily on classified advertising, was being fundamentally threatened by the rise of the internet. Circulation fell, advertising dropped, and the number of specialist correspondents in areas such as defence and foreign affairs was reduced. As senior Australian journalist, Laura Tingle, reflected: 'forced to generate 24-hour-a-day news, and under intense financial pressure, the media struggle to retain their own memory of what has gone before, and if they do to keep it - the capacity to tell a story in any longer-term context. ${ }^{20}$ Meanwhile, online access, first through desktop computers, then tablets and smart phones, was changing the way the Australian public received information about the world. Opportunities were opened up for think tanks, with electronic publications, blogs, and later social media in a market which had escaped from the traditional editorial gatekeepers of the mainstream media and the 800-word op-ed.

All these changes were important in preparing the ground for the arrival, at the beginning of the 2000s, of three new internationallyfocused institutions, each with the characteristics of think tanks, to varying degrees, and each well-funded enough to make a contribution from its inception. $\mathrm{O}^{\prime} \mathrm{Neill}$ had a founding role in all of them. On his retirement from Oxford in 2001, he returned to Australia to chair the Council of the Australian Strategic Policy Institute, Canberra, until 2005. He joined the board of the Lowy Institute for International Policy and in 2006-2007, and became Planning Director for the new United States Studies Centre at the University of Sydney.

\section{ASPI}

John Howard had come to office as prime minister in 1996 with no great background or focus on defence and foreign policy. By 1999, however, following the successful intervention in East Timor, he had

20 Tingle, Laura (2015) Political Amnesia: How We Forgot to Govern, Quarterly Essay 60, Melbourne: Black Inc. 
begun to think of himself as a national security leader. The National Security Committee of Cabinet, a Howard Government innovation, had become a central part of the machinery of government.

Howard's first Defence Minister, Ian McLaughlin, brought to the job a strong belief that policy advice needed to be contestable. Public policy reforms in New Zealand had had an impact on his thinking. At his request, the Defence Department began examining the role of think tanks and what might be done in Australia. McLaughlin's successor as minister after the 1998 election, John Moore, shared that interest.

It took until 2000 for Howard to agree formally with the idea that the government should fund, initially at least, a think tank to be called the Australian Strategic Policy Institute which would encourage and inform public debate and understanding of Australia's strategic and defence policy choices; provide an alternative source of policy ideas to government; nurture expertise in defence and strategic policy across and outside government; and promote international understanding of Australia's strategic and defence policy perspectives. ${ }^{21} \mathrm{O}^{\prime} \mathrm{Neill}$ had already been approached to chair such a body.

The third of Howard's five defence ministers, Peter Reith, oversaw the relevant legislation and signed the charter letter establishing the principle of independence. By the time ASPI became operational under Robert Hill, however, the terrorist attacks of September 2001 had brought about fundamental changes to the debate about national security policy.

ASPI was funded largely by the government which appointed its council, but it was to be independent in its views. By 2015, ASPI had 32 staff and a $\$ 6$ million budget. Most of the core budget still came from the Department of Defence, but as the institute's role expanded into other areas of national security policy, including border security and cyber security, other departments and agencies, as well as industry sponsors, made growing contributions to its budget.

21 Australian Security Policy Institute (2015) Annual Report 2014-15, Canberra: Australian Strategic Policy Institute. 


\section{Lowy Institute for International Policy}

In 2002, the founder of the Westfield retail and property business, Frank Lowy, was looking for a way of marking the 50th anniversary of his arrival in Australia with a gift to the nation. An early interest in establishing an institute to look at immigration issues gradually widened, partly at the instigation of his son, Peter Lowy, who had been resident in the United States for 15 years, into the idea of an international policy think tank based in Australia.

A member of the Holocaust generation, Lowy was deeply conscious of the importance of paying alert attention to changes in the international system. As a businessman with global interests, he also believed that Australia's successes needed to be projected better onto the international stage. ${ }^{22}$

Lowy commissioned a scoping study from Michael Fullilove, who would later become executive director of the institute, and began discussing the idea with a number of people, including Ian McFarlane, the Governor of the Reserve Bank of Australia (on the board of which Lowy sat), and Robert $\mathrm{O}^{\prime}$ Neill. ${ }^{23}$ Another prominent former Australian, Dr Martin Indyk, a think tank entrepreneur in his own right, and by then at Brookings, also provided advice.

The institute which - after some initial caution on Lowy's part carried the family name, was formally announced in September 2002, and opened in April 2003 in a heritage building close to the centre of the Sydney business district. Lowy pledged $\$ 30$ million in funding. The decision to base it in Sydney rather than Canberra was never in doubt: Lowy intended to be a hands-on chairman. But the Sydney base also had an important effect in shifting and expanding the specialist international policy debate in Australia outside Canberra.

The institute had a broad mandate, covering economic as well as political and strategic issues. Its mission was to:

- produce distinctive research and fresh policy options for Australia's international policy and to contribute to the wider international debate; and

22 Margo, Jill (2015) Frank Lowy: A Second Life, Sydney: HarperCollins.

23 Ibid. 
- promote discussion of Australia's role in the world by providing an accessible and high quality forum for discussion of Australian international relations through debates, seminars, lectures, dialogues and conferences.

The institute was to be independent, non-partisan, and empirically driven. There would be no Lowy Institute view of the world - apart from a general disposition to support an open Australia which was internationally engaged. This was an important commitment in the light of Lowy's own deep support for Israel, where he had first arrived from Europe after the war, and in whose war of independence he had fought.

The board brought together a group of people with formidable experience. It included O'Neill; McFarlane; the former senior banker, Rob Ferguson; the distinguished Australian economist and former ambassador to China, Ross Garnaut; the former Ambassador to the United States, Michael Thawley; and Peter and Stephen Lowy.

The writer was appointed as executive director, from a background largely in government policy advising and intelligence analysis. That appointment itself signalled that the institute would seek to influence practical public policy.

\section{United States Studies Centre}

One of the first major initiatives of the Lowy Institute was to commission an annual poll of Australian views of international affairs. The initial survey had revealed considerable concern about the role of the United States in the world. This helped to generate momentum from business and government supporters of the alliance for the establishment of a new centre to support understanding of the United States.

A number of earlier attempts to promote American studies in Australia had foundered through lack of resources, but in 2006 Prime Minister Howard announced the creation of a $\$ 25$ million endowment to establish a United States Studies Centre. A national competition was held, and O'Neill was asked to be the strategic advisor for the University of Sydney's bid. Sydney was successful and the centre was established there in partnership with the New York-based American Australian Association (AAA), with funding coming from the federal 
and state governments, the AAA, and various individuals, foundations and corporate sponsors. O'Neill was the first CEO until a permanent appointment was made.

The centre was a hybrid academic and research centre, although it described itself as a think tank. Its mission was 'to increase awareness and understanding about the United States in Australia'. ${ }^{24}$

During this period, established institutions responded to the same external demands. The venerable community-based AIIA strengthened its think tank dimensions, while the well-established Centre for Independent Studies expanded the range of its work in the international area.

A second round of internationally focused think tanks emerged a few years later in response to the growing policy focus on China. As with the first group, a parallel set of university centres - ANU Centre for China in the World, established in 2010, and Sydney University's China Studies Centre, which started operations in 2011 - also appeared.

The Australia-China Relations Institute (ACRI), headed by former Foreign Minister Bob Carr, was established in December 2013 at the University of Technology, Sydney, with financial assistance from a prominent Chinese Australian businessman, Xiangmo Huang. In some ways an analogue of the United States Studies Centre, ACRI defined its role, in the words of its Director, the former Foreign Minister Bob Carr, as 'leading and shaping the public debate in Australia through accessible and interactive public engagement, real time insights and a research agenda with impact' ${ }^{25}$

Another China focused think tank, the not-for-profit China Matters, followed in 2014 as a personal initiative of a leading China scholar, Linda Jakobson, formerly at the Lowy Institute, and in Beijing with the China and Global Security Programme of the Stockholm International Peace Research Institute (SIPRI). China Matters was a new model in its independence from existing institutional ties. Its role

24 ussc.edu.au/about.

25 www.australiachinarelations.org/content/acri-launch-hon-julie-bishop. 
was to 'stimulate a realistic and nuanced discussion of China among Australian business, government and the security establishment, and advance sound policy'. ${ }^{26}$

Of course, the expansion of international political and security think tanks was replicated in other areas. The Climate Institute (founded in 2005), the Mitchell Institute (established in 2013) and, most notably in terms of size and influence, the Grattan Institute, in Melbourne (which began in 2008), were established in the fields of economic and social policy.

\section{What Differences Have Think Tanks Made?}

All think tanks collect metrics to demonstrate the extent of their influence and reach to funders and supporters. Some of these metrics are simple: records of the number of events held and people present, research papers published, media coverage (including quotes from and appearances by scholars), and measures of the audience reach of websites, blogs, and social media feeds.

Another important measurement of success is finance: fund-raising in all its forms - endowments, philanthropic donations, foundation funding, corporate or individual membership, and sponsorship for specific purposes, whether from government or industry. The dependence on funding has generated increasing pressure in recent years for greater transparency in think tanks' declaration of their financial support. ${ }^{27}$

It is more difficult to measure the convening power of think tanks, that is, the quality and reputation that draws the public, policymakers and the media to think tanks and in order to introduce their ideas and research. This depends in part on their capacity to attract and maintain the interest and loyalty of a diverse group of high calibre supporters and partners, and to recruit the best scholars and researchers. In recent years, as with universities, international rankings have become another way for think tanks to define success. ${ }^{28}$

\footnotetext{
26 chinamatters.org.au.

27 www.transparify.org.

28 McGann, James G. (2015) 2014 Global Go To Think Tank Index Report, Philadelphia: University of Pennsylvania Press.
} 
Hardest of all to evaluate, however, is whether a think tank has made a difference; whether decision-makers were influenced by its ideas. Ideas are intangible and infinitely fungible. It is very difficult to ascribe a single cause to a policy change. In any case, one of the larger roles of think tanks is not simply to propose actions but to reframe the way in which issues are seen.

Over the past 15 years, think tanks have changed Australian national security policy in five particular ways: by injecting new data into the public debate; by reframing some of the ways in which Australians think about the world; by suggesting specific policy ideas; by amplifying Australian voices in the international debate, including through second track processes; and by providing a new career path for Australians interested in working on international policy.

\section{New Data}

The annual Lowy Institute poll, described by the former Prime Minister, John Howard, as 'invaluable', ${ }^{29}$ has provided a deeper and more consistent set of empirical data on the changing views of Australians about international policy questions. It has helped change the terms of the public debate on issues such as climate change, the United States alliance, and attitudes of young Australians towards democracy, and has provided a much more solid foundation for debate about community views and a way of tracing changes in them.

Similarly, ASPI's work through Mark Thomson in clarifying, analysing, and parsing the defence budget ${ }^{30}$ has helped transform the way in which the Australian defence budget is debated, and even the way in which it is publicly presented.

\section{Framing Ideas}

A second way in which think tanks have influenced Australian policy has been by helping to reframe familiar debates in new ways. For example, Rory Medcalf's work at the Lowy Institute encouraged

29 Howard, John (2015), speech at launch of Jill Margo's Frank Lowy: A Second Life, Art Gallery of NSW, 7 October.

30 Thomson, Mark (2015) The Cost of Defence: ASPI Defence Budget Brief 2015-2016, Canberra: ASPI. 
policy-makers from Labor and the Coalition to reconceptualise the country's strategic environment in Indo-Pacific rather than AsiaPacific terms. ${ }^{31}$ Alan Dupont's and Graeme Pearman's research on climate change and international security for the Lowy Institute ${ }^{32}$ helped reframe the debate about what constituted international security in Australia. Hugh White's extensive writing on Australia's 'China choice' from SDSC and the Lowy Institute ${ }^{33}$ has been another influential example of framing.

\section{Policy Proposals}

It is often hard to point to specific policy changes implemented as a result of recommendations by think tanks. Nevertheless, several examples from Australian policy in the Pacific are clear. The 2003 ASPI report by Elsina Wainwright on Solomon Islands, Our Failing Neighbour, ${ }^{34}$ provided a background to and argument for a change in government policy to support Australia's military and police intervention in Solomon Islands. Jenny Hayward-Jones's work on the role of labour mobility in Pacific development, ${ }^{35}$ and later on the need for Australia to reengage with Fiji ${ }^{36}$ was acknowledged to have been influential.

In a different area, Linda Jakobson's 2012 Lowy Institute paper on the need for a strategic dialogue with China ${ }^{37}$ played a direct role in the eventual creation of that dialogue according to government sources.

\footnotetext{
31 Medcalf, Rory (2013) 'The Indo-Pacific: What's in a Name?', The American Interest 9(2). Available at: www.the-american-interest.com/2013/10/10/the-indo-pacific-whats-in-a-name/. 32 Dupont, Alan and Graham Pearman (2006) Heating up the Planet: Climate Change and Security, Canberra: Lowy Institute for International Policy.

33 White, Hugh (2012) The China Choice: Why America Should Share Power, Melbourne: Black Inc.

34 Wainwright, Elsina (2003) Our Failing Neighbour: Australia and the Future of Solomon Islands, Canberra: Australian Strategic Policy Institute.

35 Hayward-Jones, Jenny (2008) Labour Mobility: An Australian Seasonal Work Visa Scheme for Pacific Islands Labour, Canberra: Lowy Institute for International Policy.

36 Hayward-Jones, Jenny (2014) Fiji's Election and Australia: The Terms of Re-engagement, Canberra: Lowy Institute for International Policy.

37 Jakobson, Linda (2012) Australia-China Ties: In Search of Political Trust, Canberra: Lowy Institute for International Policy.
} 


\section{Projecting Australian Voices}

As a result of the shifts in global power noted earlier, governments and diplomats in the early twenty-first century found themselves seeking to influence a much greater range of international actors beyond their familiar interlocutors in other foreign ministries. Issues as diverse as the deterrence of people smuggling and the promotion of an Australian brand abroad required new forms of diplomacy with communities beyond governments. This opened up opportunities for think tanks in areas of second track diplomacy and media exchanges. Leadership dialogues proliferated and the government supported new forms of civil society engagement such as the Lowy Institute's Australia PNG Network.

\section{Career Paths}

Given the small number of Australians working on international policy, the reluctance of public servants to engage in public debate, and the speed with which a Canberra consensus develops around most international issues, one significant result of the development of think tanks was the creation of a new career path - outside the public service and universities - for a group of people interested in international policy. This has helped bring new voices, many of them with public service experience, into an otherwise cautious public debate. It has also facilitated greater movement into and out of the national security areas of government. Although Coral Bell (and Bob O'Neill) were early pioneers of this route, by 2015, policy analysts such as Hugh White, Peter Jennings, Michael Wesley, and Rory Medcalf had operated effectively across the three distinct areas of academia, government, and think tanks. Strong internship programs also developed at the key think tanks, offering students and new graduates a taste of the work.

In weighing up the influence of Australian international security think tanks, it is less clear that they have offered fundamental challenges to existing defence, foreign, and national security policies. Indeed, they seem to have been less prepared to do so than their counterparts in social and economic policy. The reasons for this are unclear. Nevertheless, the intrinsic bipartisanship of Australian foreign policy, the need for think tankers to retain access to decision-makers, the influence of funding sources, including the government, and a common cultural 
background among participants, all impose a subtle levelling effect on debate. Any deeper or more radical enquiry about international policy is still more likely to come from independent academic research in universities.

\section{Future Outlook}

The systemic pressures which favoured the emergence of think tanks in the early twenty-first century - the normative changes which led governments to seek contestable policy advice, and the inscription on the international agenda of issues that demanded fresh strategic approaches - seem unlikely to abate. Most economic observers believe that Australian Government expenditure will be constrained for the foreseeable future, so think tanks will continue to offer potentially cost-effective ways of developing and delivering policy objectives.

Any reader of speeches by Australian defence and foreign policymakers over the past 80 years soon tires of the repetitious claims that the country is poised to enter new, more fluid and complex times. Still, it is certainly true that the challenges to the regional and global strategic order that Australia faces as a result of the rise of China will be more testing than most. Three responses have been woven through the policies every Australian government since the Second World War has used to address the nation's strategic vulnerabilities: alliance with a more powerful partner, efforts to influence the rules-based international order, and engagement with Asian neighbours to try to shape the regional environment. Each is clearly becoming harder to manage.

Bob O'Neill's 2006 prescription for think tanks: 'good ideas, dialogue with government and a relationship which tolerates free expression of views, especially on differences with existing policies', ${ }^{38}$ remains relevant 10 years later.

38 O'Neill, Robert (2006) 'Problems and Perspectives on International Security', The Lowy Lecture on Australia in the World, 27 November, Sydney: Lowy Institute for International Policy. 
This text is taken from War, Strategy and History: Essays in Honour of Professor Robert O'Neill, edited by Daniel Marston and Tamara Leahy, published 2016 by ANU Press, The Australian National University,

Canberra, Australia. 